\title{
Battling for and against rising numbers
}

LAST year may have been that in which the world (except Japan) discovered that there is something amiss with the state of public education, but only in France did the victims - lycée students - take to the streets. Elsewhere, committees were convened instead.

The Socialist government of Prime Minister Michel Rocard was clearly shaken by November's demonstrations the first upheaval in an otherwise tranquil administration. They have been taken as a sign that education should have become a "national priority" ten years ago. Yet this government and its education minister, Lionel Jospin, have set out to make real changes in the educational system. Intended reforms, it seems, are insufficient.

The plans for university reform are similarly striking. Jospin's own specialist adviser, Claude Allègre, is now putting the finishing touches to a long-term plan. A new research and doctoral studies directorate (DRED) has been set up, and aims to double the number of $\mathrm{PhDs}$ awarded each year.

Meanwhile, an Institut Universitaire de France is to be created as a sort of virtual Institute for Advanced Studies to help 15 of the best senior professors and 25 younger professors to carry out research.

Will French universities one day become major teaching and research instititions as in the United States and Britain, rather than runners-up to the grandes écoles for undergraduates and to the grandes organismes (such as CNRS) for research? That seems to be the goal.

As a stopgap measure, Jospin is building new universities (some are already well under way) to modernize and expand the crumbling tower blocks put up hurriedly in the previous expansion of the 1970 s. But the questions remain whether building can keep pace with rising student intake and, with some 1,500 lectureships vacant, where the manpower will come from.

In the United States, the gathering clouds of an economic storm darkened 1990 for the research universities in a potentially painful way. The Congress, struggling with the federal deficit, sent the federal science agencies the message that indirect costs - the supplement (as much as 80 per cent) of federal research grants that goes to pay overhead costs to research institutes - have grown, are too high and must be reduced.

Congress set a 14 per cent cap on the indirect costs of research grants in agriculture and put pressure on the National Institutes of Health (NIH) to promise action in its own field. Representative John Dingell (Democrat, Michigan), the dogged congressional watchdog, closed 1990 with a withering examination of accounting methods at Stanford University. He is planning early this year a public investigation of indirect costs as a whole.

The critics of the system have found unexpected allies among university researchers, some of whom tend to blame their institutions for the increasing difficulty of winning individual research grants. They note that while the research portion of NIH grants grew by less than 10 per cent over the past decade, the associated indirect costs grew by nearly 25 per cent.

Meanwhile, the general economic downturn in the United States threatens to push universities even closer to ruin. Tuition rates are rising out of students' reach and endowments are declining. There is rough water ahead.

The reunification of Germany could cause a nightmare of a different kind in 1991 if, as can hardly be avoided, the increased number of students brings more crowding and even longer courses.

'TOP 10' US UNIVERSITIES: BIOLOGICAL AND PHYSICAL SCIENCES (CITATIONS PER PAPER)

\begin{tabular}{llll} 
BIOLOGICAL SCIENCES & & \multicolumn{2}{c}{ PHYSICAL SCIENCES } \\
1. Rockefeller University & 7.96 & 1. Univ. Calif., Santa Cruz & 4.56 \\
2. Caltech & 7.71 & 2. Harvard University & 4.21 \\
3. MIT & 7.04 & 3. Princeton University & 3.76 \\
4. Stanford University & 6.19 & 4. University of Chicago & 3.74 \\
5. Princeton University & 6.07 & 5. Univ. Calif., Santa Barbara & 3.57 \\
6. Univ. Calif., Berkeley & 5.96 & 6. Yale University & 3.35 \\
7. Harvard University & 5.61 & 7. Boston University & 3.30 \\
8. Univ. Calif., San Francisco & 5.05 & 8. Caltech & 3.28 \\
9. Univ. Calif., San Diego & 4.59 & 9. Stanford University & 3.27 \\
10. University of Oregon & 4.58 & 10. University of Houston & 3.09 \\
\hline
\end{tabular}

These are the top universities in the United States by the yardstick of 'research quality' as determined by the average number of citations per paper in the biological sciences (biology and clinical medicine) and physical sciences (physics, chemistry, earth sciences, engineering, mathematics, and applied sciences). The figures, taken from journals indexed by the Philadelphia-based Institute for Scientific Information between 1987 and 1990, will appear later this year in Science Watch. (Data: ISI's Science Indicators Database, 1987-90.)
With its eyes on the east, the German government has made no progress in relieving the pressure on chronically overcrowded universities by hiring more faculty or restricting access. The situation will be exacerbated when thousands of young people in the the eastern Länder begin to matriculate at the better equipped universities in the west. Matters will be made even worse if, as expected, investment in the west is slowed so as to provide more money for modern lecture halls and laboratory benches in the east. It is a fine calculation whether these developments - and the lack of cash - will serve to keep the easterners close to home.

British universities, as always, are in the most precarious condition. 1990 brought yet more upheaval and confusion, principally as a result of the collapse of the attempt by the Universities Funding Council (UFC) to introduce a system of competitive bidding for funds to support undergraduate teaching. The idea was that universities wishing to expand would take advantage of supposed "economies of scale' and teach more students at a lower cost per student. The outcome would have determined student numbers and corresponding incomes at different universities for the four years 1991-95.

In the event, the universities refused to play ball, arguing that the UFC's "guide prices", meant as maximum costs in various subject areas, were too low. Bids to teach extra students did arrive, but the vast majority were at the guide prices. In October, the UFC was forced to admit defeat, suspending the bidding system.

What happens next is unclear. (The change of prime ministers is probably not irrelevant.) The UFC says it will allocate student places and teaching funds for 1991-92 in February, and give provisional figures for the succeeding three years in March. But the council has too little money for the planned expansion at the present cost per student. Many universities fear that they will be forced to charge 'top up' fees to students to maintain the quality of university education.

The UFC itself is believed to be divided over how to proceed, although whoever replaces the retiring chief executive, $\mathrm{Sir}$ Peter Swinnerton Dyer, in the Spring faces an unenviable task in restoring the UFC's battered public image.

It could well be that the central government will seek to finesse UFC's difficulty by broadening the argument, perhaps by reopening the question of whether the distinction between universities and other institutions of higher education, notably the lower-cost polytechnics, should be drawn as rigidly as at present. British universities could yet find that they have won a famous battle, but not the long war of attrition in which they have been engaged for the past two decades. 